\title{
NOG EENS DE HINDU-JAVAANSCHE BEELDEN TE BANGKOK.
}

DOOR

\author{
TH. VAN ERP.
}

(Met platen).

In deel 73 der Bijdragen van 1917, p. 285-310, deden wij eenige mededeelingen betreffende de beelden en fragmenten van den Barabudur, die de Indische regeering in 1896 geschonken heeft aan Z. M. den Koning van Siam, Chulalongkon II. In deel 79 van 1923, p. 491-518, kwamen we in ons opstel „Hindu-Javaansche beelden thans te Bangkok" daar op terug naar aanleiding van een door tusschenkomst van den Nederlandschen gezant verkregen stel fotografische negatieven van het meerendeel der Javaansche stukken, waarbij zich ook fragmenten bevonden van het vermaarde Lara Djonggrang-complex te Prambanan en van het Oost-Javaansche heiligdom Tjandi Singasari.

Dat we nu nogmaals dit onderwerp ter sprake brengen, vindt zijn grond in de omstandigheid, dat wij eenige interessante nadere inlichtingen ontvingen, zoomede een stel foto's, die in menig opzicht beter zijn dan de meerendeels slechte opnamen van den Bangkokschen fotograaf van 1922 .

Deze nieuwe gegevens danken we aan den Inspecteur van den Oudheidkundigen Dienst in N. I., Dr. P. V. van Stein Callenfels, die zich in September 1926 in opdracht der N. I. regeering naar Malaka begaf voor het instellen van prehistorische onderzoekingen ${ }^{1}$ ).

Van het verblijf in Perak werd geprofiteerd om een uitstapje te ondernemen naar Bangkok, niet direct ,,in de buurt”, want de treinreis Haiping-Bangkok duurt twee volle etmalen! Tijdens het ruim 14-daagsch verblijf in Siam's hoofdstad werd een 10-tal opnamen

1) Deze leverden, naar ons werd medegedeeld, belangrijke resultaten op; met spanning zien we de publicatie hiervan tegemoet. 
gemaakt van de Javaansche stukken, die zich thans bevinden in een museum, dat in October 1926 tot stand is gekomen onder leiding van Prins Damrong, broeder van wijlen Z. M. Chulalongkon, en van den bekenden Franschen Indo-archaeoloog George Coedès.

$\mathrm{Bij}$ de behandeling van Callenfels' gegevens zullen we tegelijkertijd een paar foto's publiceeren, die het Instituut in September 1925 werden toegezonden door den te Bangkok woonachtigen Heer W. Blankwaard.

Allereerst zij nog eens in herinnering gebracht welke Javaansche stukken in 1896 naar Siam's hoofdstad verhuisden.

Dit waren:

A. Van den Barabudur.

1o. Vijf Dhyani-Buddha's uit de nistempeltjes, resp. van het Oosten, Zuiden, Westen en Noorden en van den allerhoogsten Zenithmuur. Eén hiervan verongelukte bij het inschepen ter reede van Semarang. De vier overigen staan thans tegen hoekpijlers van Bangkok's heiligste pagode, gelegen binnen de ommuring van de in 1785 gestichte Wat Phra Keo, een der weinige Siameesche gebouwencomplexen, die met zorg in goeden staat worden gehouden. De wijze van opstelling blijkt uit plaat I (foto Blankwaard). Het beeld, de mijmer-Buddha van het Oosten, werd voorzien van een nieuw lotuskussen en ruggestuk met vlammenrand in quasi Hindu-Javaanschen stijl en kreeg ook nog een rugkussen, alles in stucco ! Men voelt de disharmonie, die hier heerscht tusschen het klassieke Hindu-Javaansche beeld en de met mozaiek en barok pleisterwerk bekleede, moderne pijlers. Maar soit ! de Buddha's belandden ten slotte op gewijden bodem, waar ze door Hinayanisten worden bewierookt en vereerd en ze zetten luister bij aan Bangkok's meest befaamden tempel van den ,,smaragden Buddha”, ,het verheven Juweel”. Deze naam slaat op een vermaard Buddha-beeld, dat uit één stuk nephriet gebeiteld is en in het hoofdaltaar is opgesteld. De Wat Phra Keo is feitelijk het oude, z.g. "groote paleis" der Siameesche Vorsten. De tegenwoordige koning houdt er slechts zelden verblijf. Behalve op bepaalde feestdagen, is het slechts na verkregen toestemming te bezichtigen. De oude audiëntie-zaal verheugt zich in zekere beruchtheid vanwege de beide hideuse, kolossale poortwachters nabij den ingang. Deze geweldige, groteske Yaksa's zijn opgebouwd in baksteen en geheel bekleed met fayence tegels.

2o. Het eenige gave stel bijeenhoorende leeuwen van het stupaplein, die als wachters fungeerden bij den Noordelijken toegang. De 
singha's zijn volgens Callenfels' mededeelingen ,met de dhyaniBuddha's destijds door Z. M. Chulalongkon definitief aan den tempel geschonken en dus onaantastbaar geworden van heiligheid". De afbeeldingen in ons vorig opstel waren ontleend aan de minderwaardige cliché's van den Bangkokschen fotograaf. Wie zich een beter denkbeeld wil vormen van de aesthetische waarde en de allure dezer wachters, vergelijke plaat $3 \mathrm{~b}$. van ons artikel „De Leeuwen van den Barabudur", Bijl. E. van het Oudheidkundig Verslag van 1923, waar een dergelijke leeuw is voorgesteld, die in brokstukken te voorschijn kwam bij de ontgraving van het stupa-plein, op het Oosten, in het jaar 1907.

De singha's zijn opgesteld in den lusttuin van de Wat Phra Keo, onder de pendopo, afgebeeld op plaat 2 (foto Blankwaard). Men krijgt hier een goeden indruk van het rommelige milieu met zijn decadente, moderne pleister-architectuur, zijn mengelmoes van beelden. Op den voorgrond twee naturalistisch nagebootste koebeesten, smakelooze Westersche tuinplastiek in zink.

3o. Een tempelwachter, een unicum, dat zeer waarschijnlijk dienst heeft gedaan als hoeder bij den ingang van de sangharama, het klooster, dat oudtijds bij den Barabudur stond, en dat thans spoorloos verdwenen is.

Van dezen tempelwachter gaven wij in ons vorig opstel een afbeelding, ontleend aan een door Dr. Krom in het Ethnogr. Museum te Leiden aangetroffen oude foto. Onze plaat 3 laat het beeld van een andere zijde zien en is vervaardigd naar een opname van Dr. van Stein Callenfels. Het bevindt zich thans in bovengenoemd Museum. Wanneer wij deze afbeelding vergelijken met de oudere, dan zien we dat de tempelhoeder in zijn nieuw vaderland een nieuwen (pleister)neus heeft gekregen.

Wij hebben vroeger reeds gewezen op het betreurenswaardige verlies van dezen wachter, doch kunnen de verleiding niet weerstaan dit nog eens te accentueeren door het stuk te stellen naast een overeenkomstig exemplaar uit de Prambanan-vlakte. We kiezen daartoe den poortwachter, die in 1923 opgegraven werd in de desa Glondong bij Kalasan en overgebracht naar het erf van den Regent aldaar ${ }^{1}$ ) en verwijzen naar plaat 4 . Het is een der vier wachters, die paarsgewijze de beide toegangen bewaakten van het gebouwencomplex, welks overblijfselen 130 Meter ten Zuiden van den Tara-

1) Oudheidkundig Verslag 1923, p. 79. 
tempel van Kalasan ${ }^{1}$ ), werden aangetrof fen en dat zeer waarschijnlijk het klooster was, waarvan sprake is in de stichtingsoorkonde van genoemd heiligdom ${ }^{2}$ ).

We hebben hier te doen met een indrukwekkend meesterstuk, dat het toch zeker niet onfraaie Barabudur-exemplaar verre achter zich laat in monumentaliteit en schoonheid. We hoeven hier niet verder den lof te verkondigen van den onbekenden beeldhouwer, die deze wachters hiew uit trachietblokken van ongeveer drie meter hoogte en kunnen dit gerustelijk overlaten aan de afbeelding. Maar wel dient de aandacht gevestigd te worden op de tegenstellingen tusschen het Barabudur- en het Kalasan-stuk. Bij alle overeenkomst in vormgeving en stijl - beiden blijven binnen het kader der klassiek Midden-Javaansch plastiek - zien we bij den eenen wachter een archaisch aandoende rust en eenvoud, een ietwat primitieve vormgeving in de oogpartij, handen en voeten, een sobere behandeling in de haardracht, de kleedij en lijfsieraden. Bij den ander een meer bewogen en expressief karakter, een rijper modelé, vooral in het gelaat (de oogpartij !) de handen en voeten, een rijkere behandeling van de lijfsieraden en haardracht; de laatste met vijf rijen krullen, in stede van twee en deze op zich zelf, sprekender dan bij het Barabudur-beeld. Men lette op de ornamentatie van heupkleed en gordel en op de verfijnde versiering van de knots. Maar bovenal, hoe meesterlijk werd hier de compositie door die kostelijke vondst, om het been, waarop geknield wordt, te doen rusten op een afzonderlijk gehouden, fraai versierde plaat!

We zien hier het zelfde verschijnsel, dat zich voordoet bij vergelijking van de architectuur, de versiering en de bouwtechniek van Barabudur en Mendut eenerzijds, met Tjandi Kalasan (778 A.D.) anderzijds, een verschijnsel, dat er o. i. op wijst dat de beide eerstgenoemde heiligdommen tot een oudere periode hooren dan het laatste ${ }^{3}$ ). Nog eens, het voor Java verloren gaan van den archaischen wachter van den Barabudur moet ten zeerste worden betreurd.

4o, Een makara-spuier van den ondersten hoofdmuur der breede omgang. In stede van de slechte afbeelding van den Bangkokschen fotograaf, in ons vorig artikel, waarin de kunstwaarde van het fragment niet tot haar recht komt, en deze bovendien geschaad wordt door onbeholpen afdekking van den achtergrond, geven we nu

1) Twee andere wachters sieren den tuin der Residentswoning te Jogja; het vierde exemplaar houdt zich nog schuil en zit vermoedelijk nog veilig in den grond.

2) Krom, Inleiding Hindoe-Javaansche Kunst, I, p. 201.

3) Naar men weet is de stichtingsdatum van den Barabudur niet bekend. 
Callenfels' goede foto, plaat 4 , die ons tevens een kijkje gunt op de opstelling in het museum.

We brengen nog even in herinnering dat dit prachtige stuk bouwbeeldhouwkunst thuis hoort op den Noord-West-hoek van den stupa. Bij de restauratie is de ledige plaats aangevuld met een andere, in de nabijheid uit den bodem te voorschijn gekomen spuier, doch deze laatste moest op zijn beurt vervangen worden door een plompen U-vormigen gootsteen.

5o. Een Kalakop-spuier van een der vier gaanderijmuren. We verwijzen hiervoor naar de vrij goede afbeelding bij ons vorig artikel. Callenfels zond geen foto en vermeldt het stuk niet bij de museumobjecten. Vermoedeliịk staat het dus nog in de pendopo.

6o. Een nagenoeg compleet, sprekend relief, afkomstig van de balustrade der eerste gaanderij, bovenste reeks waar jataka's zijn uitgebeeld. In ons vorig opstel, p. 505, hebben we betoogd dat het vermoedelijk no. 186 was der bedoelde jataka-serie. We waren toen aangewezen op een zeer slechte foto en de Bangkoksche fotograaf had bovendien, bij het naar buiten brengen en opnieuw opstellen der dertien steenblokken, de twee bovenste rijen verhaspeld. Aan den Heer Callenfels danken we nu een betrouwbare foto, plaat 5. Deze is, wat belichting betreft, nog niet om er ons over op te winden, doch de opstelling der steenstukken is nu correct.

Het relief geeft zeven voortschrijdende vrouwen te zien; op het incompleete einde een paar doodskoppen en doodsbeenderen. Vroeger schreven we o.m.: „Nu is de foto, jammer genoeg, zóó slecht, dat wij slechts aarzelend durven aan te nemen dat de vrouwen de slangen-coiffure vertoonen. Is onze onderstelling juist, dat wij hier met nagini's te doen hebben, dan zou het tafereel zich uitnemend aansluiten bij de vier volgende tableaux, $187 \mathrm{t} / \mathrm{m}$. 190, waarin ook naga's en nagini's optreden." Helaas geeft ook Callenfels' foto hier geen uitsluitsel. Bij de drie voorste figuren is de coiffure verbrijzeld, bij de vier anderen doet ze, wat de contour betreft, wel denken aan de slangen-huif, maar toch meenen we hier eer bloemen te zien dan slangen. Hoe het ook zij, de hoofdtooi is een zeer bizondere en kan

Krom heeft gemeend dien op epigrafische gronden te moeten stellen op de tweede helft der achtste eeuw. Op kunsthistorische gronden zouden wy dien zoo ver mogelyk naar achteren verlegd willen hebben, liefst naar de eerste helft der achtste eeuw en daarbij zóó dicht bij het jaar 732 der Tjanggalinscriptie, als overeen te brengen is met den overgang van het oude Çiwaitische gezag naar hẹt Mahayaniștische regiem der vorsten uit het Çailendra-geslacht. 
voor iconografen wellicht een belangrijk gegeven behelzen bij de identificatie van het relief.

Callenfels zond ook een foto van de achterzijde van het relief, doch deze is dermate gesluierd, dat ze niet voor reproductie in aanmerking komt. We zien een deel van het relief op den achtergrond van plaat 5 . Het geeft een zittende vrouwenfiguur, de linkerhand in den schoot, als de Dhyani-Buddha's van het Oosten, Zuiden en Westen, in de opgeheven rechterhand een lotusbloem. Overigens het normale decor, links een vaas met lotus-bouquet, rechts een wierookbrander, aan den bovenkant het guirlande-motief. Zooals bekend is, hebben we hier te doen met een der decoratieve tableaux, zooals die aan de buitenzijde der balustraden voorkomen, tusschen de Buddhaschrijnen. Doorgaans is er afwisselend een manlijke en een vrouwelijke figuur afgebeeld. Indien onze onderstelling juist is, dat we hier relief no. 186, onmiddelijk ten Zuiden van de Westelijke poort, voor ons hebben, dan zou er bij de poorten een afwijking te constateeren vallen in het schema, want het tableau ten Noorden van de poort geeft ook een vrouw te zien. Zeer waarschijnlijk is er geen kwestie van een afwijking, doch vormden de poorten het uitgangspunt voor een symmetrische indeeling dezer half-goddelijke wezens, die zulk een voorname rol spelen in het pantheon en de plastiek der Mahayanisten.

7o. Een Kala-kop, afkomstig van de omlijsting van een Buddhaschrijn der gaanderijen. We schreven vroeger: „Mogelijk is hiervan te Bangkok nog een tweede exemplaar voorhanden", zulks naar aanleiding van ons op den Barabudur mondeling verstrekte inlichtingen. Deze twijfel kan nu verdwijnen. Callenfels zond een foto van het eenig voorhanden exemplaar, mede opgesteld in het museum, plaat 7 .

8o. Een stupa, behoorend tot de bekroningen van de nistempeltjes.

\section{B. Van het Lara Djonggrang-complex te Prambanan.}

9o. Een decoratief figuur-relief met drie apsarasen, afkomstig van de buitenzijde der balustrade van den Çiwa-tempel. De slechte afbeelding bij ons vorig opstel kan nu vervangen worden door Callenfels' duidelijke foto, plaat 8 . We schreven vroeger: „Eén en hetzelfde architectonische motief is hier in 48-malige herhaling toegepast. Het bestaat uit een tusschen pilasters gevatte en door een Kala-makara-ornament bekroonde nis, geflankeerd door inspringende kazementen. Het voorvlak van genoemde nissen bestaat uit 
één enkelen steen, versierd met drie in uiterst bevallige houding naast elkaar staande figuren, welke elkander somwijlen omstrengelen. Meestal zijn het drie vrouwen, soms een man tusschen twee vrouwen, dan weer drie mannen. Op de inspringende paneelen zijn dansende en musiceerende figuren afgebeeld". We kunnen thans de situatie verduidelijken met een fraaie foto en verwijzen naar plaat 9 , die een beeld geeft van een deel der gereconstrueerde prachtige balustrade ${ }^{1}$ ). Doch tevens dient een kleine correctie te worden aangebracht. Het nismotief herhaalt zich feitelijk 72 maal, met dien verstande dat op de acht uitspringende hoeken er telkens twee gecombineerd zijn tot één bouwkundige eenheid. Voorts is ons in 1926, tijdens onze deelname aan den arbeid der z.g. „Restauratiecommissie" gebleken, dat er oorspronkelijk een bepaald systeem heeft geheerscht in de groepeering der drie typen van nis-steenen. Er waren slechts acht groepen met een gandharwa tusschen twee apsarasen en deze kwamen voor in de middelste der vijf nissen, die men op de voorzijde van elken gevel-uitsprong vindt, wederzijds van de trappen. De twee andere typen, t.w. die met de drie apsarasen en de drie gandharwa's, zijn gelijkelijk verdeeld over de resteerende 64 nissen ${ }^{2}$ ).

De reconstructie van de balustrade heeft, behoudens het aanbrengen der stupa-vormige bekroningen, sinds lang haar beslag gekregen. In tal van nissen vindt men beschadigde reliefs; bij verscheidene zijn de kopjes der figuren afgeslagen, doch bij registratie bleek ons dat er slechts een drietal reliefs dermate verminkt zijn, dat ze onleesbaar werden en dat er slechts één totaal verdwenen is. We weten nu dat dit ééne verloren schaap in het Bangkoksche museum is ondergebracht.

10o. Een steen met sprekend relief, waarop vier apen voorkomen. In stede van het vroegere onduidelijke prentje geven we thans Callenfels' foto, plaat 10. De belichting is niet fraai, maar 't relief is althans in allen deele leesbaar. We brengen nog even in herinnering dat de Rama-legende op de binnenzijde der balustrade van den Çiwa-tempel in beeld gebracht is tot en met de episode van het bouwen van den dam en de overtocht naar Langka. Het verhaal vond eertijds zijn voortzetting op de balustrade van den Brahma-

1) Oudtijds werd elke nis bekroond door een monumentaal, geribd, stupavormig topstuk.

2) Met deze systematische groepeering der drie typen van voorstellingen werd bij de reconstructie, jammer genoeg, geen rekening gehouden. 
tempel, doch ten gevolge van de blootlegging door Dr. Groneman - een meesterstuk in het slechte! - waren de stukken schier hopeloos verspreid geraakt. Intusschen is de Oudheidkundige Dienst thans aardig op weg de voorhanden fragmenten herplaatst te krijgen. De onverflauwde toewijding en speurzin van den fotograaf-teekenaar J. J. de Vink mag hier wel even met dankbaarheid worden herdacht.

Het is duidelijk dat de reliefsteen van plaat 10 strijders te zien geeft van Hanuman's leger en dus hoort tot de balustrade van den Brahma-tempel. Onder de wapens noteeren we een zware dolk, doch onze bizondere aandacht wordt getrokken door een vervaarlijken bijl, een sierlijk staatsie-wapen. Het lemmer heeft de gedaante van een maansikkel en doet denken aan dat van een hellebaard; het boveneinde lijkt versierd met een vogelkop.

11o. Twee sprekende steenen, waarvan volgens Callenfels er één behoort tot den Brahma-tempel, en de andere tot den Wishnutempel. Wij geven hier wederom de nieuwe prenten plaat 11 en 12 , en herinneren er aan, dat Callenfels' in 1915 ondernomen onderzoek reeds onomstootelijk heeft vastgesteld dat de balustrade van den Wishnu-tempel versierd is geweest met uitbeeldingen van de Krishna-legende.

Welk een milde innigheid in het groepje met de drie zittende manlijke figuren, waarvan de twee voorsten in een zeer vertrouwelijk gesprek gewikkeld schijnen; welk een bewogenheid in het tafereel met de kampende boogschutters. Hoe fraai is het modelé van den staanden krijger, die ons zijn rugzijde toekeert. Men voelt wel dat deze fragmenten, in aesthetisch opzicht, op het zelfde hooge peil staan als de Ramayana-reliefs van den Çiwatempel en dat ze door dezelfde meesterhanden werden gebeiteld.

In ons vorig opstel wezen wij reeds op een eigenaardig costuumdetail: de merkwaardige, uit drievoudige (kralen- of parel ?) snoeren bestaande kransen op het hoofd der drie figuren van plaat 12. Opmerkelijk is ook de haardracht met de recht naar achteren stekende wrong en leerzaam voor de stijltradities van dien tijd is de achterste der drie figuren. Het hoofd is frontaal uitgebeeld en de haarwrong is dus feitelijk niet zichtbaar. Doch de beeldhouwer laat die wrong parmantig naast het hoofd uitsteken: een combinatie van vóór- en zijaanzicht. De inheemsche drang naar uitbeelding van het karakteristieke profiel-beeld, die later in de Oost-Javaansche relief-kunst zoo sterk zal gaan spreken, doet zich hier al gelden. Of vergissen wij ons, en hebben wij hier te doen met een schuin naar 
achteren opgewerkte haardracht, zooals bij den bekenden kop van Sukuh uit het $Z_{\text {wolsche museum }}{ }^{1}$ ) en zooals die nu nog op Bali in zwang is bij de vrouwen?

Wij vestigden vroeger de aandacht op een ,indekking met ruitvormige houten sirappen" van het bouwsel op den achtergrond. $\mathrm{Nu}$ we over een betere afbeelding beschikken, dient dit te worden herzien. Het gebouwtje is een kleine open balé op vier stijlen, met het typische Sumatraansche dak. De lange zijkanten zijn voorzien van een schuinstaand zonnescherm van gevlochten bamboe, ondersteund door twee stutten; deze laatste zijn gebroken, doch wij hebben het ontbrekende met een paar lijnen aangevuld. Wat wij voor sirappen aanzagen, blijkt dus bamboe-vlechtwerk te zijn.

Wij hebben vroeger melding gemaakt van ,een vijfde fragment van Tjandi-Prambanan", omdat daarvan sprake is in de officieele briefwisseling, die vooraf ging aan de schenking. Toen bij de negatieven van den Bangkokschen fotograaf dit vijfde stuk niet voorkwam, schreven wij: „Het is gewenscht dat hieromtrent een nader onderzoek worde ingesteld". De Heer Callenfels, die tijdens zijn verblijf in Bangkok, ons opstel niet in zijn bereik had, heeft dit niet gedaan, doch zijn foto's behelzen alleen de vier tot nu toe behandelde stukken. Wellicht hebben we aan te nemen dat er inderdaad niet vijf, maar slechts vier Prambanan-fragmenten naar Siam's hoofdstad zijn verhuisd.

\section{Van het Singasari-terrein.}

12o. De prachtige, $1.70 \mathrm{M}$. hooge Ganeça van de alun-alun van Singasari, die volkomen gelijkwaardig is met het uit den torentempel afkomstige exemplaar, dat zich thans te Leiden bevindt. We verwijzen hieromtrent naar onze vroegere mededeelingen met goede afbeelding. Wij herinneren even aan de opstelling op een voetstuk, opgebouwd uit de bekende à jour bewerkte, groen geglazuurde Chineesche tegels; rechts en links een Chineesch heiligen-beeld, op den voorgrond een offertafel met Chineesch vaatwerk. Alzoo een mengeling van goede Hindu-Javaansche en Chineesche kunst! Wat de Siamees daaraan van zich zelve toevoegde, dat is de opbouw van het voetstuk met zijn ribben en lotuskussen in stucco... is foeileelijk.

In de of ficieele briefwisseling is sprake van een tweede beeld. Hieromtrent brachten de gegevens van 1922 geen opheldering. Ook Callenfels zwijgt er over.

1) Zie Krom, Inleiding Hindu-Javaansche kunst, pl. 88. 
7. Hiermede hebben de Javaansche stukken, die naar Siam verhuisden, de revue gepasseerd en hebben wij ze nog eens gezien in het nieuwe licht, dat daarover opging, dank zij de gegevens van de Heeren Blankwaard en Callenfels.

Wij onthielden ons in ons vorig opstel van lang napleiten en jammeren over de vergissing van 1896, doch besloten het met een opwekking. Wij gaven in overweging een poging te doen een gedeelte der beelden en fragmenten te doen terugkeeren naar de plaats van herkomst. Wij formuleerden een bescheiden wensch en spraken de hoop uit dat de Oudheidkundige dienst in N. I. het denkbeeld bij de Indische regeering ingang zou doen vinden om, door bemiddeling der Nederlandsche regeering en van den Gezant te Bangkok, een verzoek te richten tot den Koning van Siam.

Dit is niet geschied en wellicht zijn daarvoor goede redenen geweest. Het blijft nu eenmaal een netelige onderneming, terug te komen op een schenking. Toch zal nu een deel van onze wenschen in vervulling gaan. De Heer Callenfels heeft zich, tijdens zijn verblijf te Bangkok, niet bepaald tot het fotografeeren van de museumstukken. Hij heeft tevens een poging gedaan langs onderhandschen weg de drie sprekende reliefsteenen van Prambanan (pl. 10, 11 en 12), naar de plaats van herkomst te doen terugkeeren. Van terzijde vernamen we dat deze poging met succes zal worden bekroond. De stukken zullen geruild worden tegen vier Hindu-Javaansche bronzen uit de collectie duplicaten van het Museum te Batavia.

De onderhandelingen werden aangeknoopt met Prins Damrong. Deze stond van den aanvang af sympathiek tegenover Callenfels' wenschen en gaf zelfs te kennen dat hij voor zich persoonlijk, in het belang van de wetenschap, niets liever zag dan dat de stukken terugkeerden naar de plaats van herkomst, doch tevens verklaarde hij machteloos te staan tegenover de verknochtheid van Koning en volk aan Chulalongkon's ,geschenken aan de natie”. Callenfels schrijft: „De oude koning was tijdens zijn leven al zeer bemind en is nu goed op weg een heilige te worden, of liever, hij is het al. Ik zag groote processies van bedevaartgangers, waarbij tal van Buddhistische monniken, naar zijn ruiterstandbeeld trekken, vóór de troonzaal. De beelden worden beschouwd als geschenken van hem aan de natie en deelen in zijn heiligheid".

De eindelooze besprekingen hadden dan ook een moeizaam verloop en ware het niet dat wijlen Chulalongkon's bewondering en liefde voor Hindu-Javaansche bronzen nu nog nawerkte, dan zou zelfs de idee der ruiling geen ingang gevonden hebben. Een goed deel van 


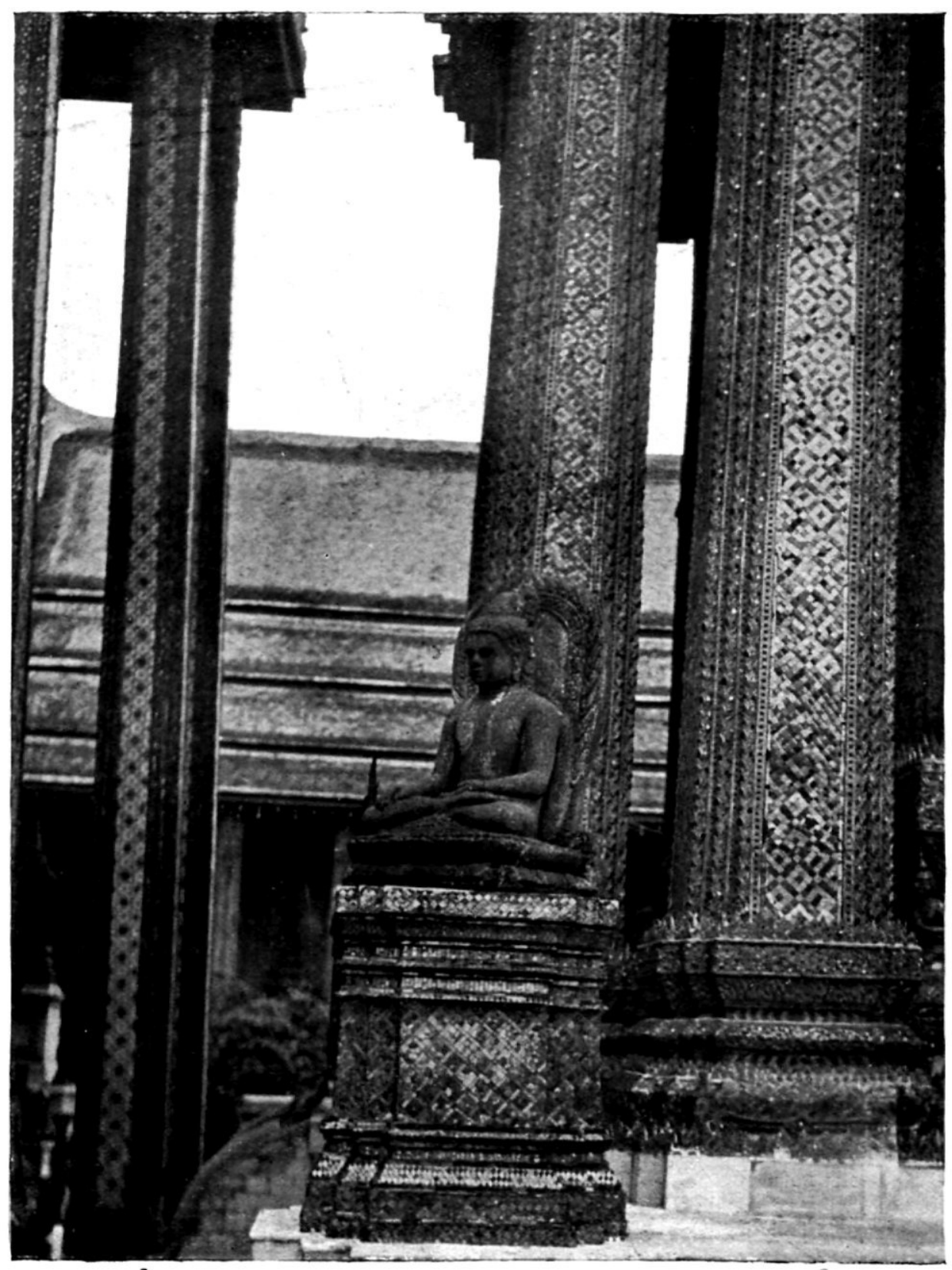

1. Dhyani-Buddha van Barabudur in de pagode van Wat Phra Keo te Bangkok. 


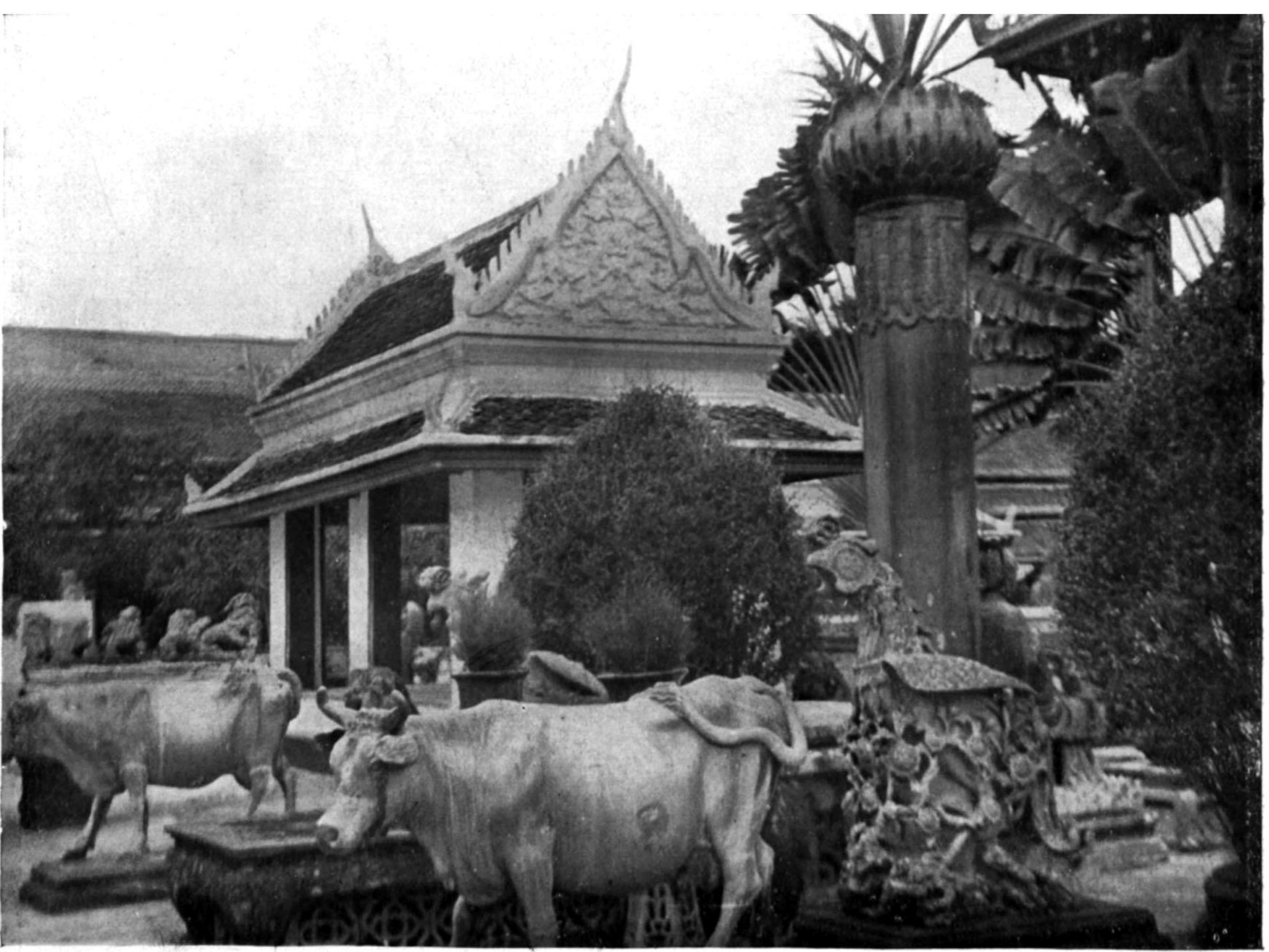

2. Kijkje in den lusttuin van het oude "groote paleis"; onder de $_{\circ}$ pendopo staan eenige Hindu-Javaansche fragmenten. 


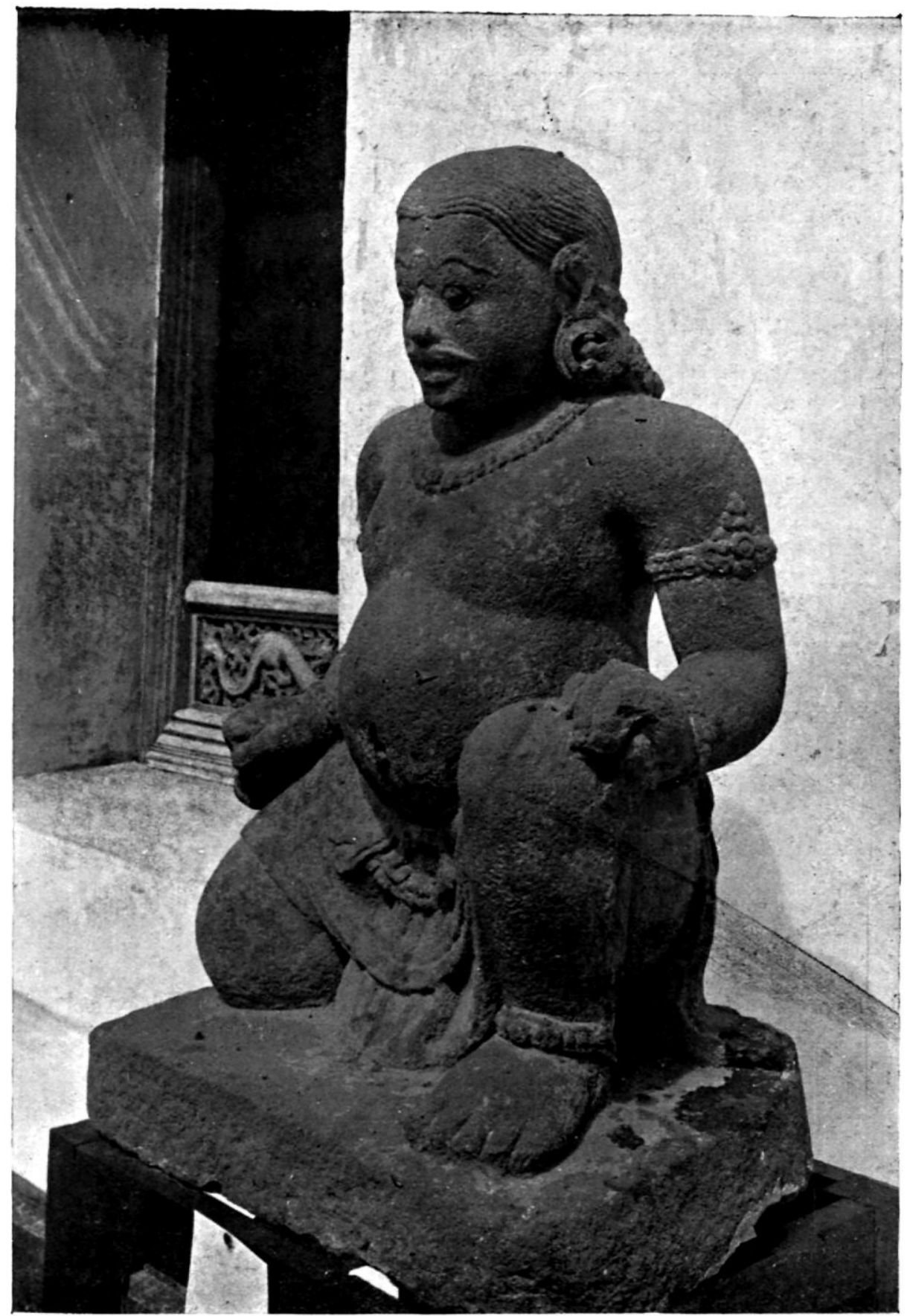

3. Tempelwachter van het Barabudur-terrein, thans in Museum te Bangkok. 


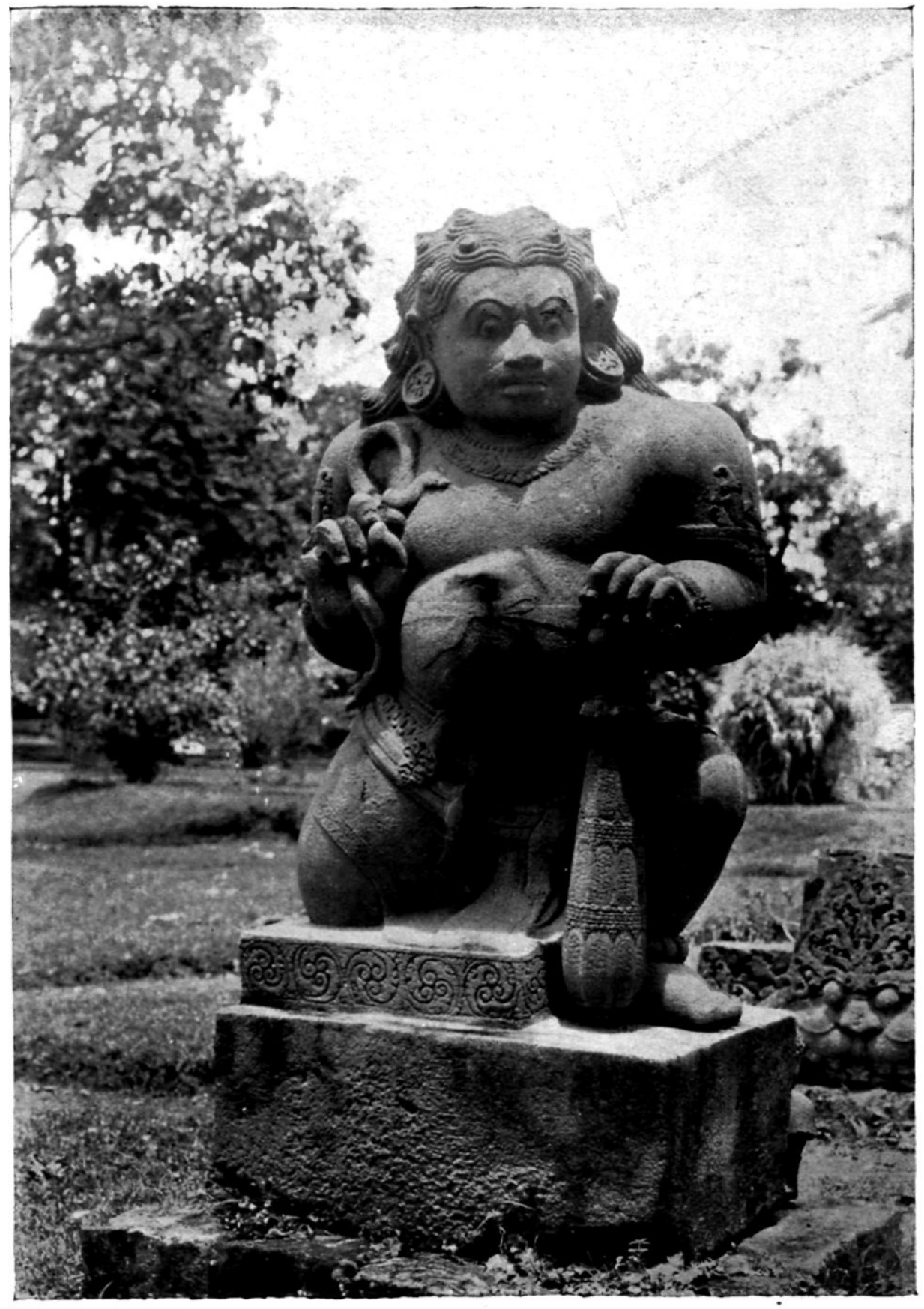

4. Tempelwachter afkomstig van het klooster (?), behoorende bij den Tara-tempel van Kalasan, thans op het Regents-erf aldaar. 


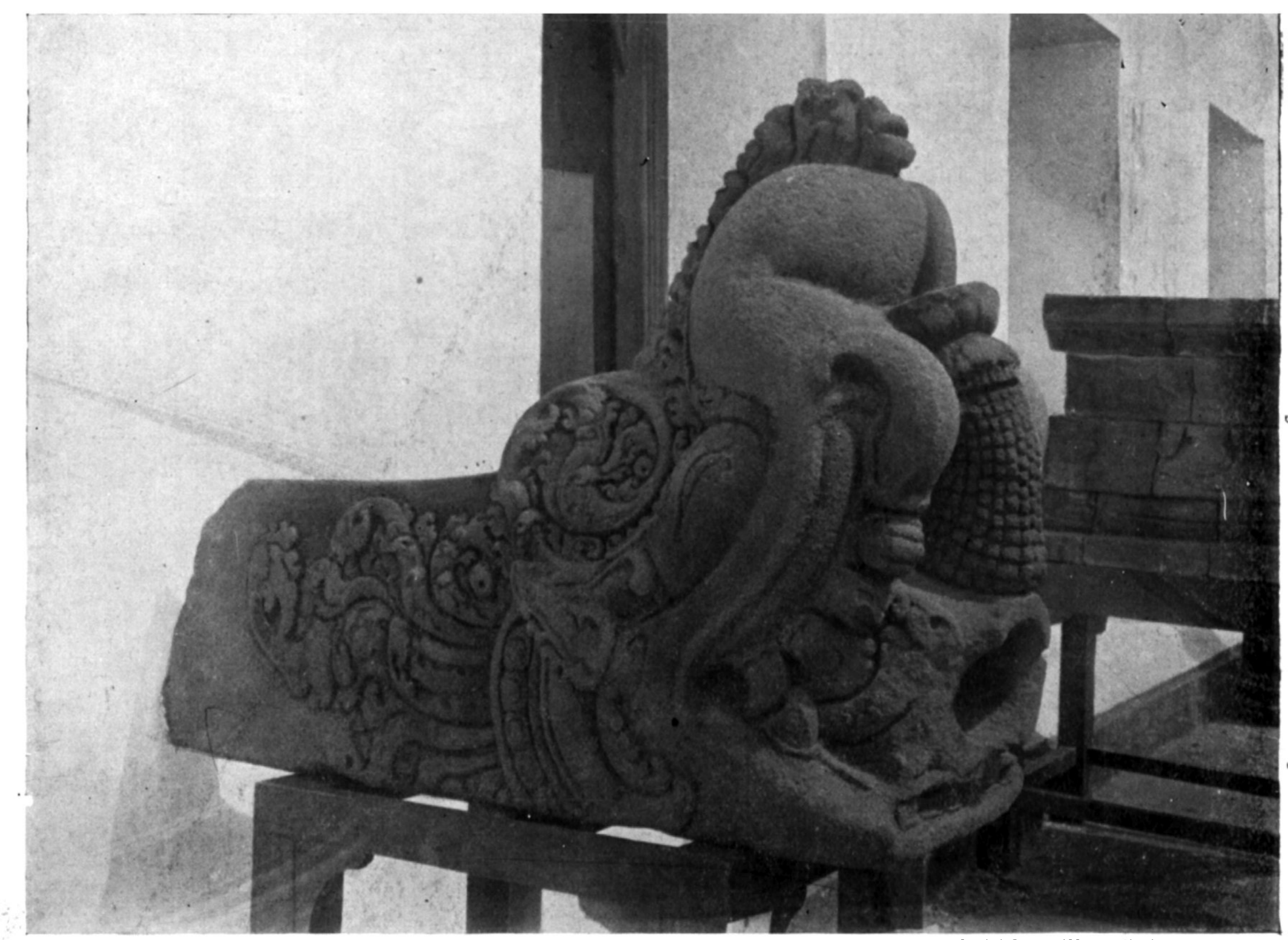

5. Makara-spuier van Barabudur, thans in Museum te Bangkok. 


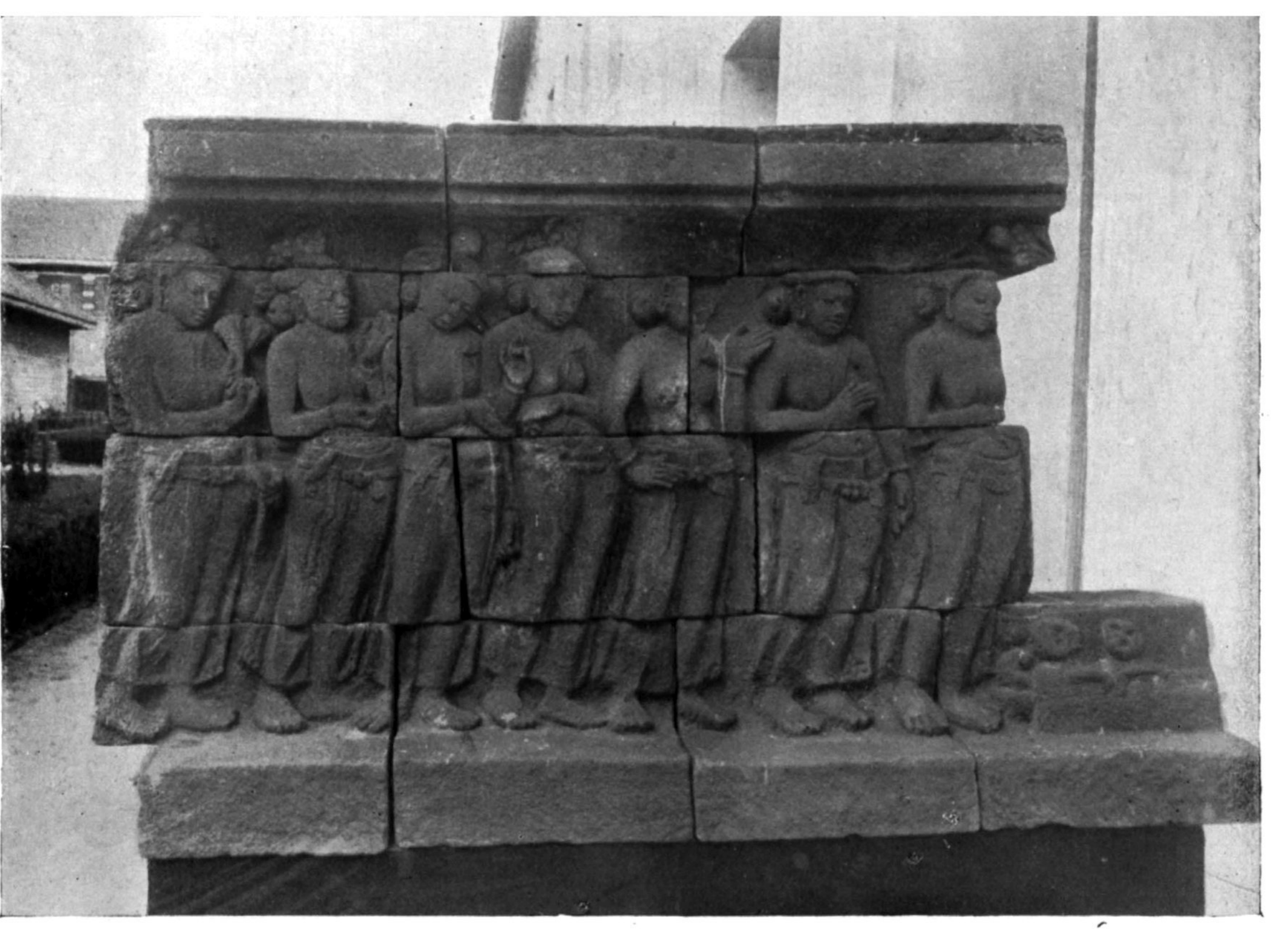

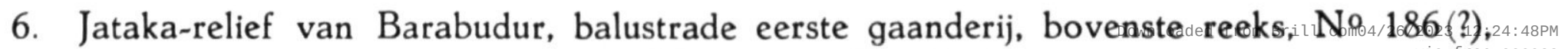
thans in Museum te Bangkok. 


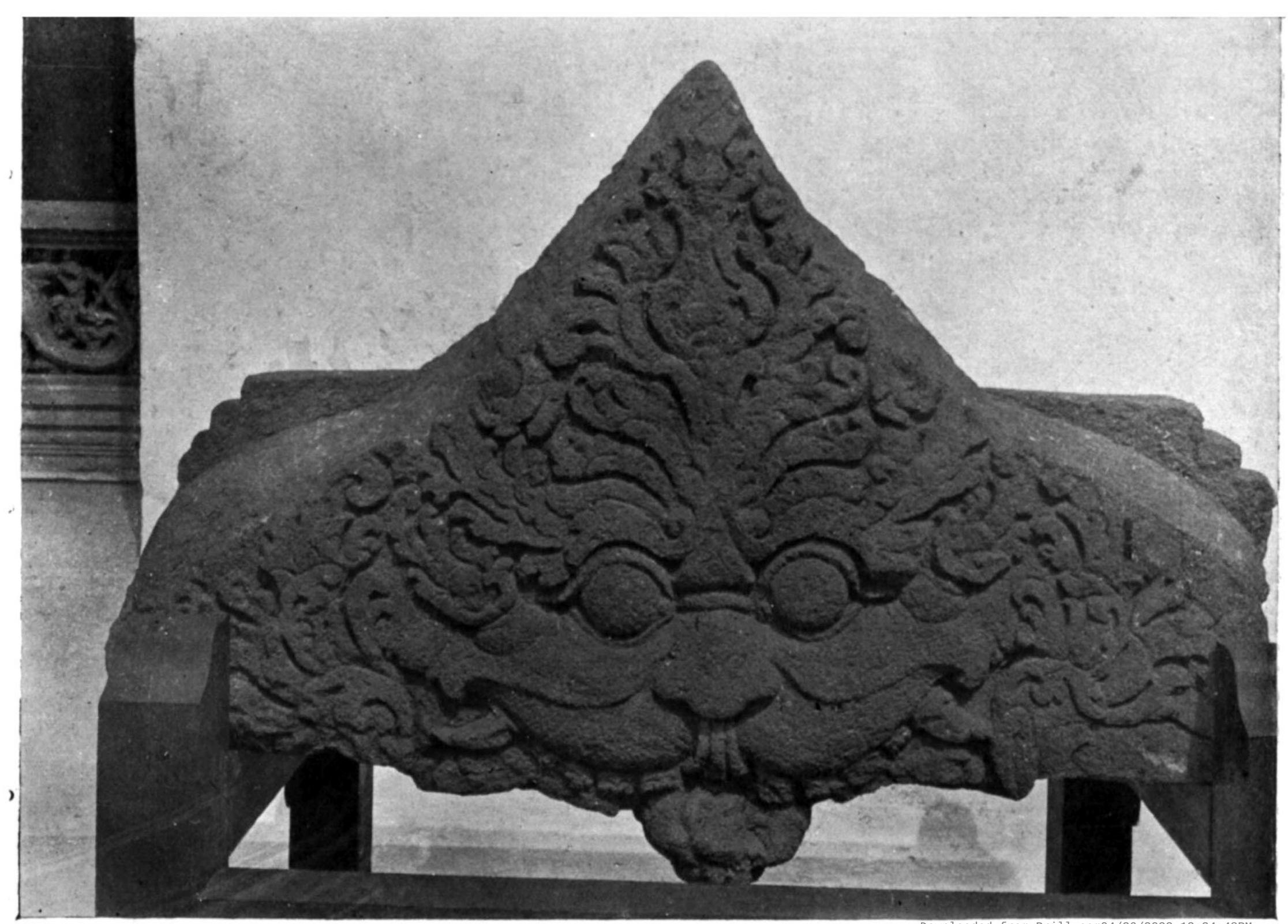

7. Kala-kop van een nistempeltje van Barabudur, thans in Museum te Bangkok. 


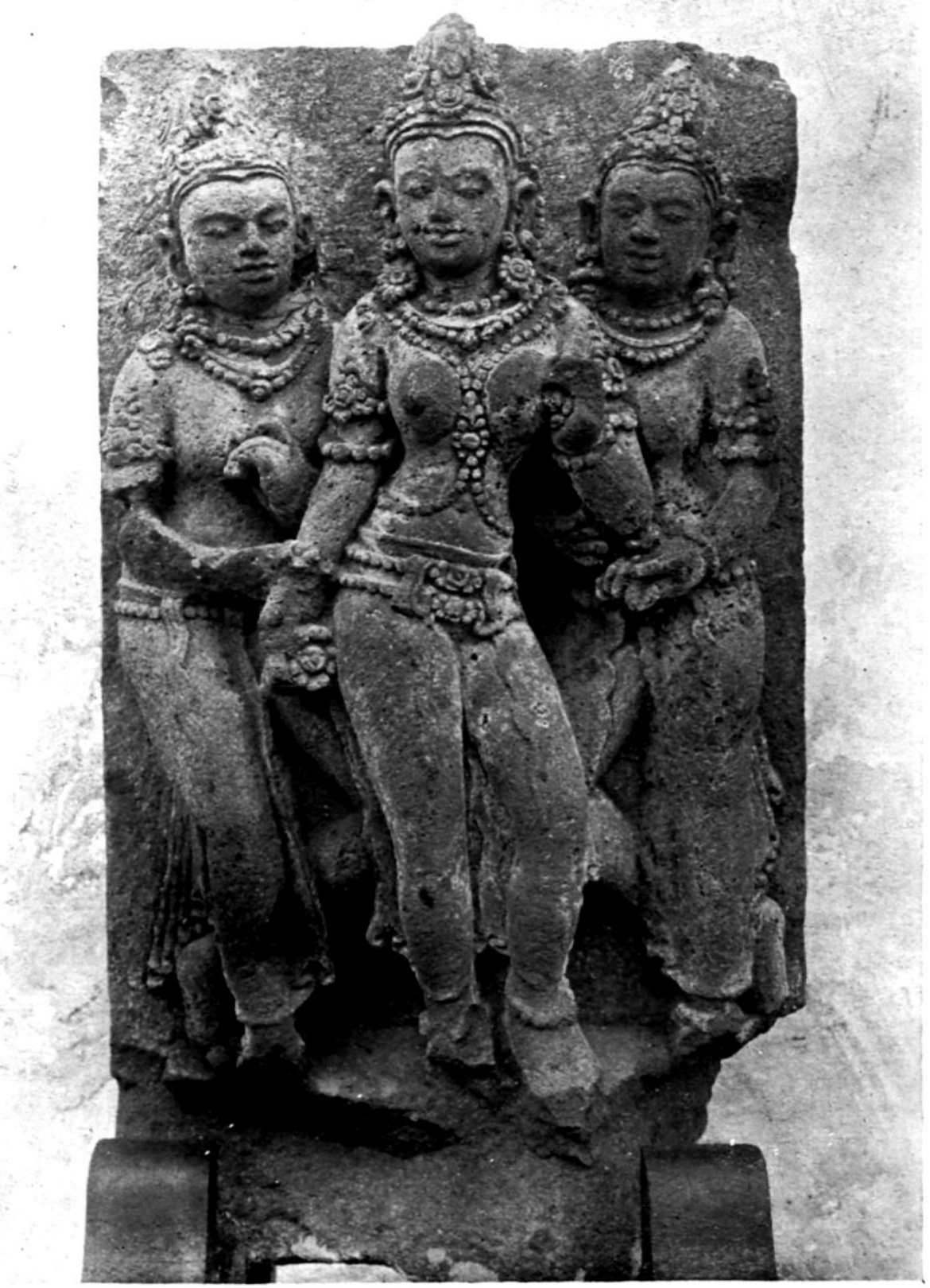

8. Nis-steen met Apsarasen, afkomstig van de balustrade van den Çiwa-tempel van Prambanan, thans in Museum te Bangkok. 


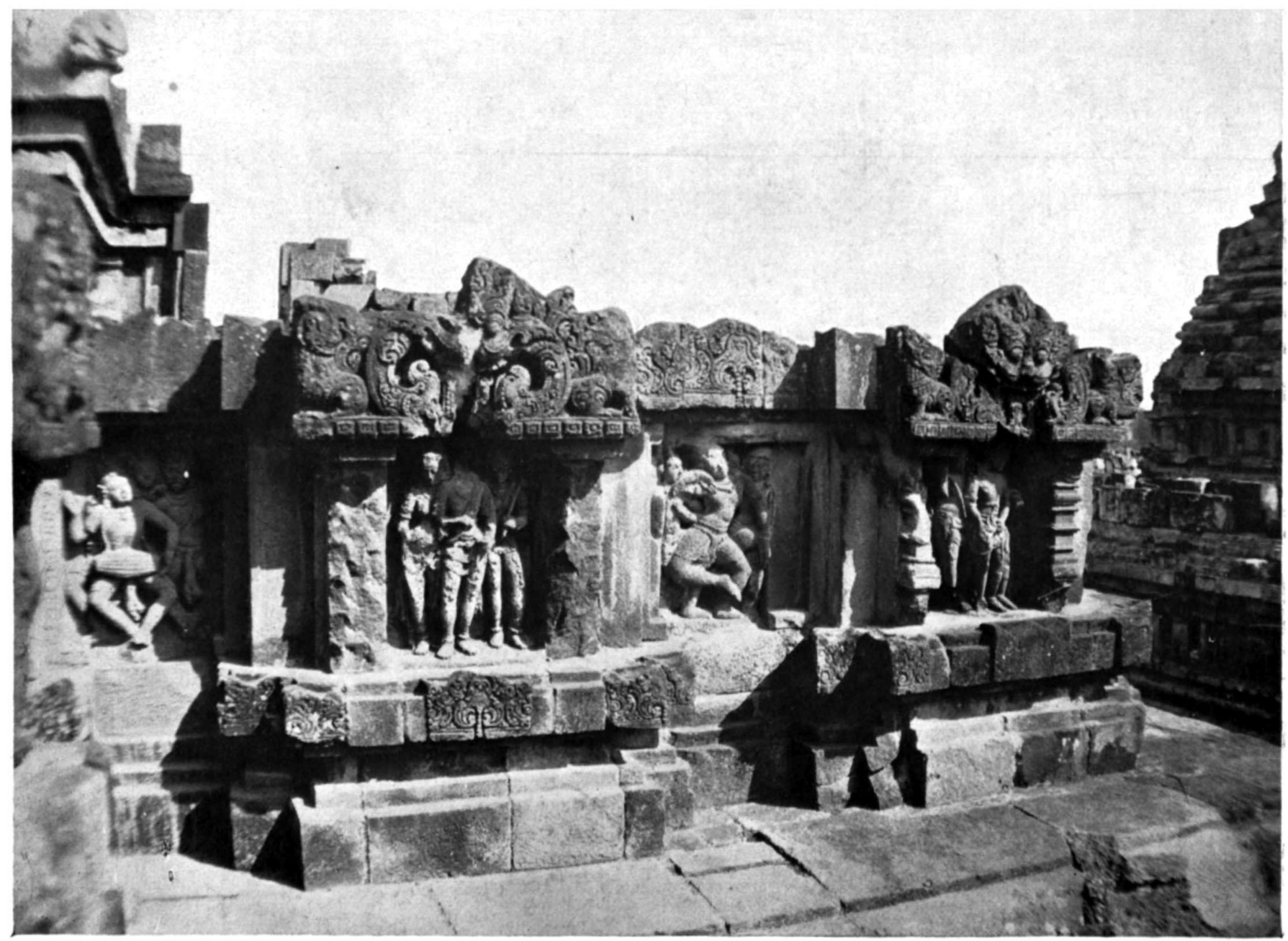

9. Çiwa-Tempel van Prambanan. Gereconstrueerde nissen der balustrade. 


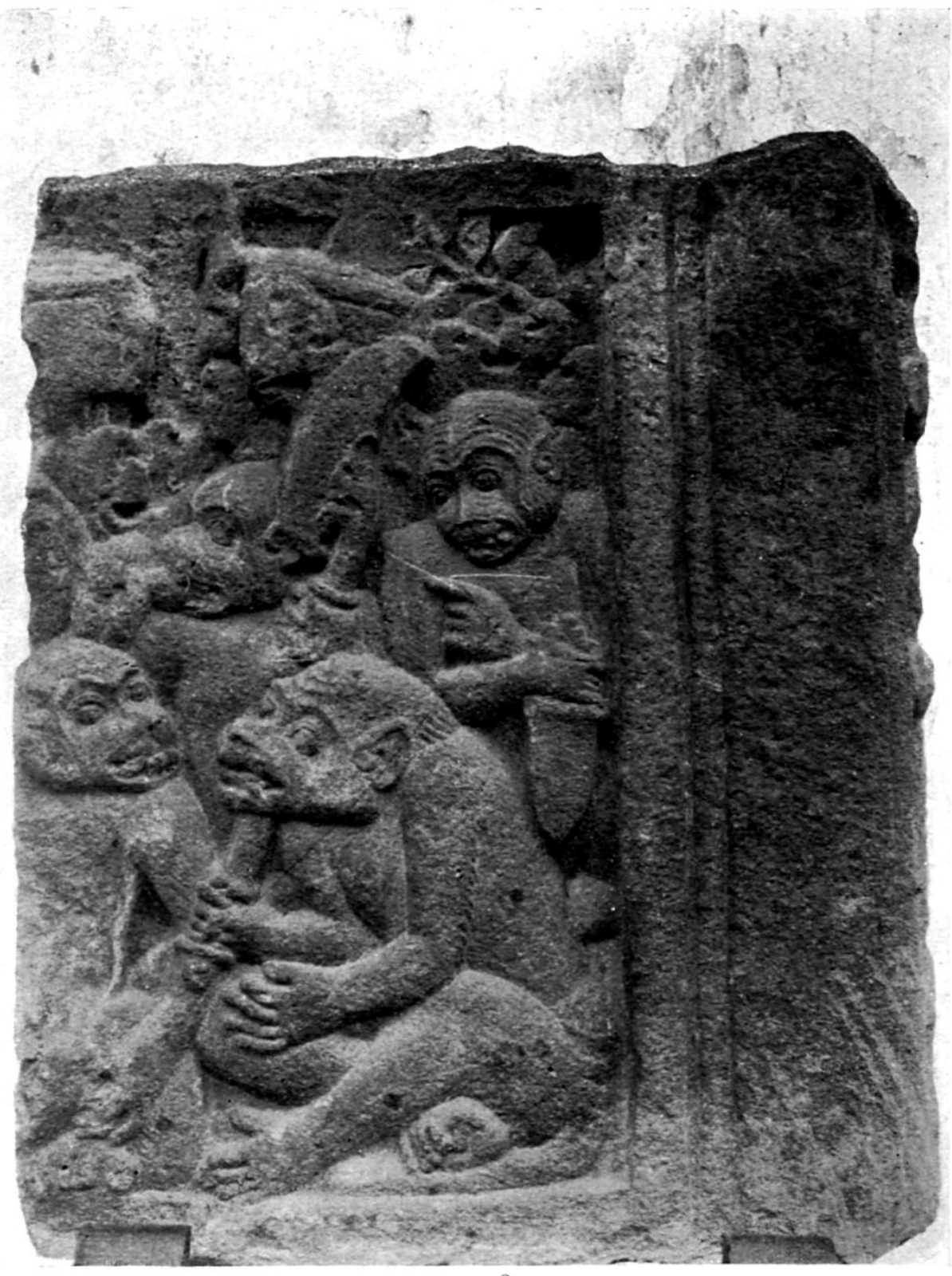

10. Fragment der Ramayana-reliefs van de balustrade van den Brahma-tempel van Prambanan, thans in Museum te Bangkok. 


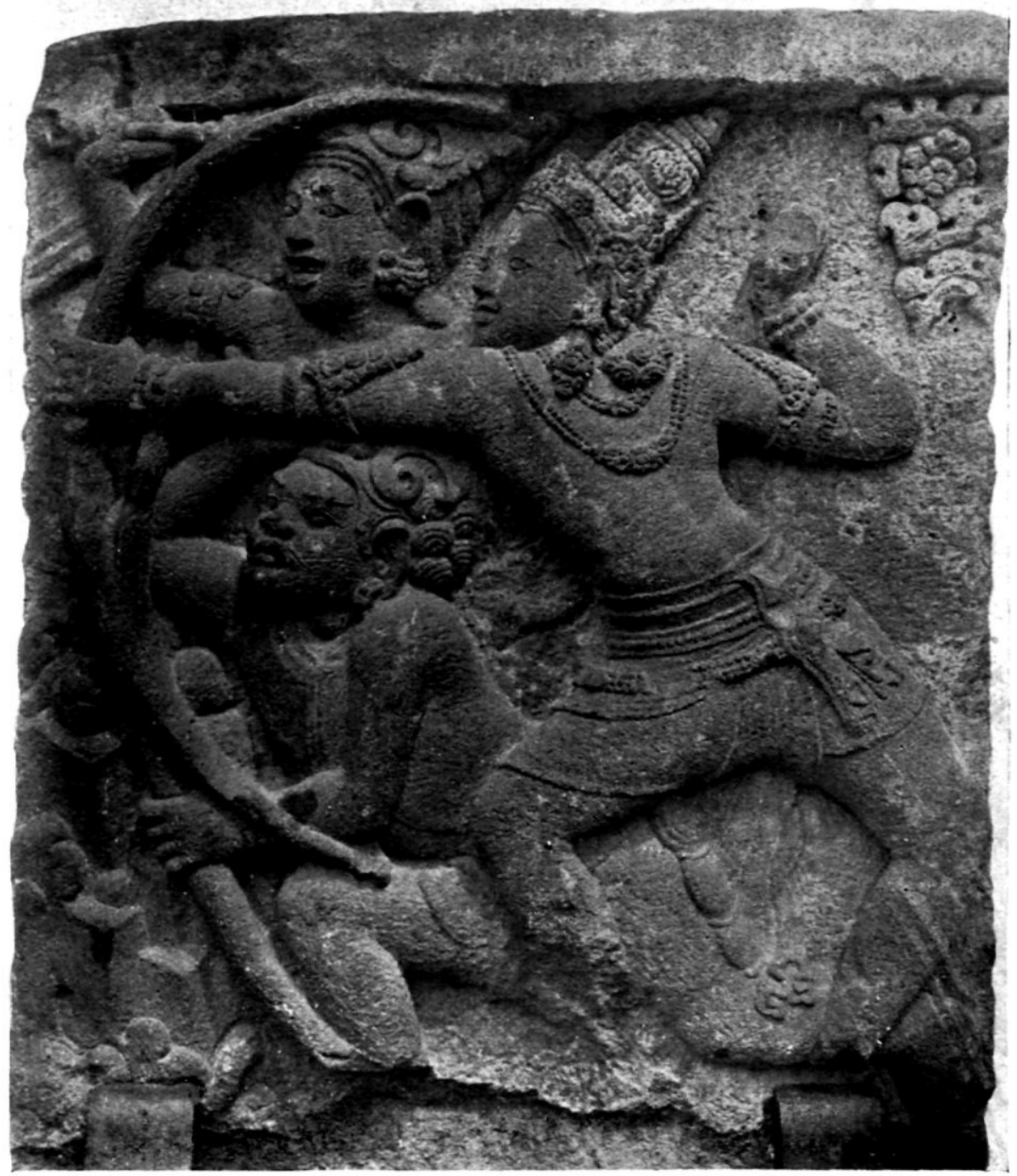

11. Fragment der Ramayana-reliefs van de balustrade van den Brahma-tempel van Prambanan, thans in Museum te Bangkok. 


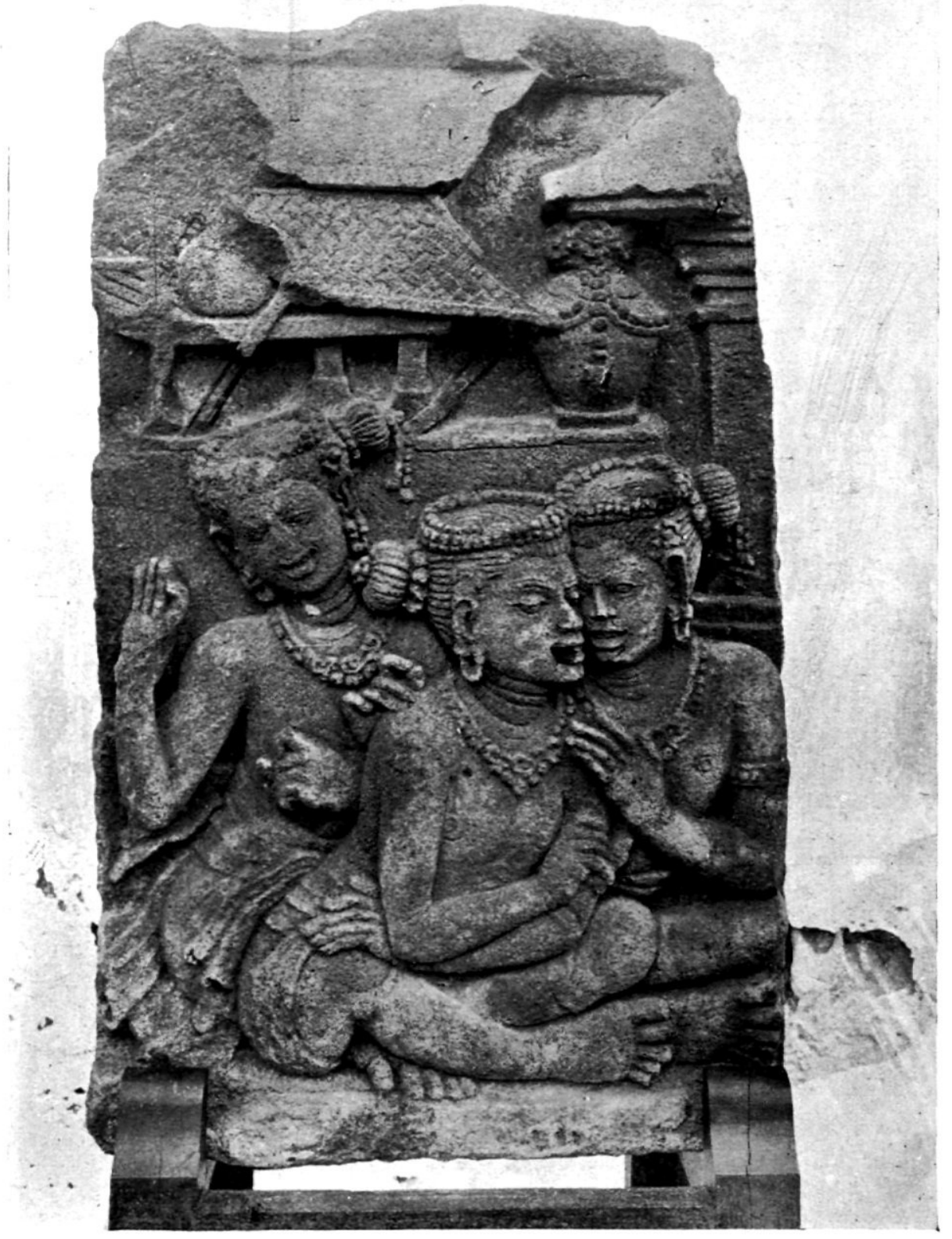

12. Fragment der Krishnayana-reliefs van de balustrade van den Wishnu-tempel van Prambanan, thans in Museum te Bangkok. 
het slagen is te danken geweest aan de krachtige medewerking van George Coedès. Ook deze bevestigde nadrukkelijk dat de ,heiligheid van Chulalongkon's geschenken aan de natie" geen phrase is, maar levende werkelijkheid.

En zoo blijft het terugerlangen van de stukken, die eenmaal aan den tempel geschonken werden, en ter eere waarvan eens een luisterrijk wijdingsfeest plaats had, t.w. de vier Dhyani-Buddha's en de beide leeuwen van den Barabudur, ten eene male buitengesloten.

Callenfels schrijft nog dat de eenige kans om, behalve de drie bedoelde Prambanan-fragmenten, nog enkele andere der museumstukken terug te krijgen, daarin zou bestaan, dat wij eenige oude Siameesche stukken in ruil wisten te bieden. Ook in Siam uit de nationale opleving zich blijkbaar in dien zin, dat men thans groote waarde hecht aan al wat vastzic aan eigen, oude cultuur. Wie weet hoe schaarsch oude nobele Siameesche plastiek is, begrijpt dat de kans langs dezen weg nog iets terug te krijgen, al heel gering is.

Intusschen zullen binnen afzienbaren tijd drie waardevolle fragmenten, na een ruim dertigjarige ballingschap op terugreis gaan naar good old Prambanan. Twee pijnlijke leemten in de Rama-serie van den Brahma-tempel, en één in de Krishna-serie van den Wishnutempel, zullen eerlang worden aangevuld.

Onze hulde aan Van Stein Callenfels' initiatief, aan Prins Damrong's ruimen geest en Coedès' krachtdadigen steun !

Den Haag, Juni 1927.

\section{NASCHRIFT VAN 26 DECEMBER.}

Met verwijzing naar het op p. 507 opgemerkte over den steenen wachter van Kalasan, zij hier mededeeling gedaan van een zeer recente en belangrijke vondst.

Den len November werd in een suikerriettuin, 300 à 400 Meter ten Zuiden van den Tara-tempel, dus op de plaats, waar oudtijds de gebouwen stonden, die vermoed worden tot de sangharama te behooren, een monumentale bronzen klok opgegraven van 57 c.M. hoogte. Dit kan niet anders dan de oude kloosterklok wezen. De Adjunct-Inspecteur van den Oudheidkundigen Dienst, de Heer B. de Haan, in wiens beproefde handen de leiding berust van de restauratie van den Tara-tempel, schreef ons dienaangaande dd. 11 November:

„Het is een buitengewoon fraai exemplaar, prachtig van verhouding en rijk van versiering. Het geheel heeft den stoepa-vorm en wordt bekroond door een steigerend leeuwtje. Merkwaardig is het Chineesche karakter van dit figuurtje. Als het afzonderlijk gevonden ware, zou men het eer onder Oost-, dan onder Midden-Javaansche kunst rangschikken. Vlak naast de klok werd nog een groote Chineesche pot gevonden". Het te velde staande gewas stond het verdere bodemonderzoek voorloopig in den weg. Dit zal echter na den rietoogst weer worden ter hand genomen.

DI. 83. 